\title{
Field measurement of survival rates of juvenile Acanthaster planci: techniques and preliminary results*
}

\author{
John K. Keesing, Andrew R. Halford \\ Australian Institute of Marine Science, PMB No. 3, Townsville MC, Queensland 4810, Australia
}

\begin{abstract}
Techniques are described which enable measurement of mortality rates of post-metamorphic Acanthaster planci (L.) as small as $0.5 \mathrm{~mm}$ in the field. Results indicate that mortality rates at this time are significant, viz. $6.49 \% \mathrm{~d}^{-1}$ for 1 -mo-old starfish (mean size $=1.1 \mathrm{~mm}$ ) decreasing to 1.24 and $0.45 \% \mathrm{~d}^{-1}$ for $4-(2.7 \mathrm{~mm})$ and 7 -mo-old $(5.5 \mathrm{~mm})$ starfish respectively. Experiments involving exclusion of predators indicated that the major source of mortality was predation by epibenthic fauna. Results also show that in the presence of adequate food supply juvenile $A$. planci move very little. This suggests that survival will be enhanced by settling in areas where predation will be minimal.
\end{abstract}

\section{INTRODUCTION}

Population outbreaks of the crown-of-thorns starfish Acanthaster planci (L.) remain the most important management issue on coral reefs in the Indo-Pacific region (Birkeland \& Lucas 1990). In common with most marine invertebrates, a major barrier to understanding the population dynamics of $A$. planci is that very little is known about the juvenile stage of life and the factors that affect survival at this stage. Variability in postsettlement survivorship has been demonstrated for a number of taxa and is dependent on a number of factors including habitat type, settlement density and predation (Cameron \& Schroeter 1980, Keough \& Downes 1982, Young \& Chia 1982, 1984, Luckenbach 1984, Keough 1986, Rowley 1989, 1990, McShane 1991).

Acanthaster planci have a 2 wk planktonic period after which larvae settle and metamorphose into 5armed starfish about $0.5 \mathrm{~mm}$ in diameter (Yamaguchi 1974). They live in a complex habitat of dead coral rubble (Yokochi \& Ogura 1987) and feed on coralline algae. After about 4 to $6 \mathrm{mo}$ at a size of about $10 \mathrm{~mm}$ the starfish change their diet and begin to feed on corals and grow much more rapidly (Yamaguchi 1974).

\footnotetext{
- Contribution Number 825 from the Australian Institute of Marine Science
}

Little is known of the mortality patterns of small A. planci, but that they are readily consumed by crabs (Lucas 1973) and under some circumstances field populations may be greatly affected by disease (Zann et al. 1987).

It is known that starfish outbreaks on reefs can be initiated by large recruitment events (Zann et al. 1987. Doherty \& Davidson 1988). Some recruitment rates of Acanthaster planci have been measured and have been found to vary both on a temporal scale and spatially both between reefs (Doherty \& Davidson 1988) and within reefs (Zann et al. 1987, Yokochi et al. 1988). However just how recruitment rates are related to rates of larval settlement is not known and whether any significant reduction in starfish numbers or some sort of regulatory control acts on starfish populations prior to them reaching a size at which recruitment can be measured with any accuracy (e.g. about $20 \mathrm{~mm}$ or 8 mo old; Zann et al. 1987 ) is not known (Keesing \& Halford 1992). In order to establish what levels of starfish settlement/recruitment on reefs are necessary to precipitate outbreak numbers of adults 3 yr later, it is necessary to have an understanding of the mortality rates of small starfish and the factors which influence them.

To determine what factors are important to Acanthaster planci population dynamics we have developed techniques to work with juvenile $A$. planci as small as 
$0.5 \mathrm{~mm}$ in the field. These techniques enable mortality rates to be measured under near natural conditions The purpose of this paper is to describe these techniques and present the results of field deployment of 1-, 4-, 7-and 16-mo-old laboratory-reared A. planci juveniles.

\section{MATERIALS AND METHODS}

Large numbers of small juvenile Acanthaster planci were reared in December-January $1989 / 90$ and 1990/91 using techniques similar to those described by Birkeland \& Lucas (1990). Full details of the rearing operation are to be described elsewhere. Field deployment experiments were carried out in February 1991 (1 mo post-settlement), May 1991 (4- and 16-mo-old) and August 1991 ( 7 -mo-old). Starfish were deployed in the field in plastic boxes with tight-fitting lids. Three sizes of commercially available plastic boxes were used. Boxes $26 \times 18 \times 8 \mathrm{~cm}$ deep were used to deploy 1 - and 4 -mo-old starfish. Larger boxes were used to deploy 16-mo-old starfish $(35 \times 25 \times 12 \mathrm{~cm})$ and 7 -mo-old starfish $(57 \times 32 \times 9 \mathrm{~cm})$. The lids and sides of the 2 smaller box types were covered in $0.2 \mathrm{~mm}$ mesh (Fig. 1a) and $0.5 \mathrm{~mm}$ mesh was used to cover all surfaces of the larger boxes (Fig. 1b). The lids of the largest of the boxes did not fit as well as those on the smaller boxes and some problems with starfish escape were subsequently encountered (see below). The boxes containing starfish were deployed on the leeward side of Davies Reef $\left(18^{\circ} 50^{\prime} \mathrm{S}, 147^{\circ} 39^{\prime} \mathrm{E}\right)$ at a depth of ca 12 to $15 \mathrm{~m}$ in an area of dead coral rubble (Fig. 1c).

The basic aim of the experiments was to compare the survival of small starfish living in their natural habitat [among dead coral coated in crustose coralline algae and other organisms; see Yokochi \& Ogura (1987)] with that of starfish living among a similar substrate which provided a food source and shelter, but in the absence of potential predators or other hazards. For the natural rubble treatment (hereafter TREATMENT), pieces of unconsolidated dead coral rubble complete with algal and motile epifaunal assemblages were collected directly from the seabed at the time of deployment. For the control rubble treatment (hereafter CONTROL), sun-bleached or beach-collected coral rubble was used after conditioning in flow-through aquaria for several weeks to allow a biological coating of bacteria, diatoms, filamentous and coralline algae to grow on the rubble surface. Benthic diatoms provide an adequate food source for young juvenile starfish (author's unpubl. data).

The starfish reared in the laboratory and the conditioned rubble were taken to the field in $100 \mathrm{l}$ tanks aboard a research vessel. They were then transferred to the deployment site in a small inflatable boat. Conditioned rubble was placed into the CONTROL boxes on the surface at the deployment site while rubble from the seabed at the deployment site was collected by divers and placed in the TREATMENT boxes and then brought to the surface. Batches of starfish which had been counted out previously were then washed into the CONTROL and TREATMENT boxes and the lids were fitted. The boxes were then gently lowered into the water to allow any trapped air to escape and taken to the bottom by divers where the boxes were tied to concrete blocks using rubber straps.

Initial densities varied for each experiment depending on the availability of starfish at different ages. One hundred of the 1-mo-old starfish were stocked to each of the boxes for the first experiment (equivalent to 2137 ind. $\mathrm{m}^{-2}$ ), 35 per box of 4 -mo-old ( 748 ind. $\left.\mathrm{m}^{-2}\right), 20$ per box of 7 -mo-old (110 ind. $\mathrm{m}^{-2}$ ) and 10 per box of 16-mo-old (114 ind. $\mathrm{m}^{-2}$ ). Starfish sizes could not be measured prior to deployment (but see Table 1).

Water exchange in boxes. The mesh on the boxes was cleaned each day or every second day by lightly brushing to ensure water flow was not occluded by silt. To assess the adequacy of water flow, water samples were syringed from the boxes periodically over the course of 1 experiment and the dissolved oxygen content was measured using an ICI Dissolved Oxygen Meter. Water samples were also taken from CLOSED boxes (no possible water flow) and boxes within boxes (DOUBLE MESH; Fig. 1c) which had been deployed with natural coral rubble. Fluoroscein dye was also injected into some extra boxes to further examine the effect of the caging on water flow.

Escape controls. Ten boxes for each of the CONTROL and TREATMENT types were used for the 1 -, 4 - and 7 -mo-old starfish whilst 5 natural rubble TREATMENT boxes only were used for the 16-mo-old starfish. Two variations of the boxes were used for deployment of the 1-,7-and 16-mo-old Acanthaster planci. Five replicate OPEN treatment boxes (the same as TREATMENT boxes but without lids) were deployed with 7 -mo-old $A$. planci. These OPEN boxes allow free movement of starfish and predators in and out of the boxes. In order to examine movement rates of the small starfish and their propensity to escape from the OPEN boxes, we used small boxes without lids inside larger boxes. These are termed ESCAPE controls and were deployed for the 1-,7-and 16-mo-old starfish. Upon recovery of the boxes we counted the number of starfish that had moved out of the smaller inner box into the larger outer box.

Recovery of deployed starfish. After the boxes had been in place for $6,13,16$ and $13 \mathrm{~d}$ for the $1-, 4-, 7$ - and 16-mo-old starfish respectively, they were collected by 

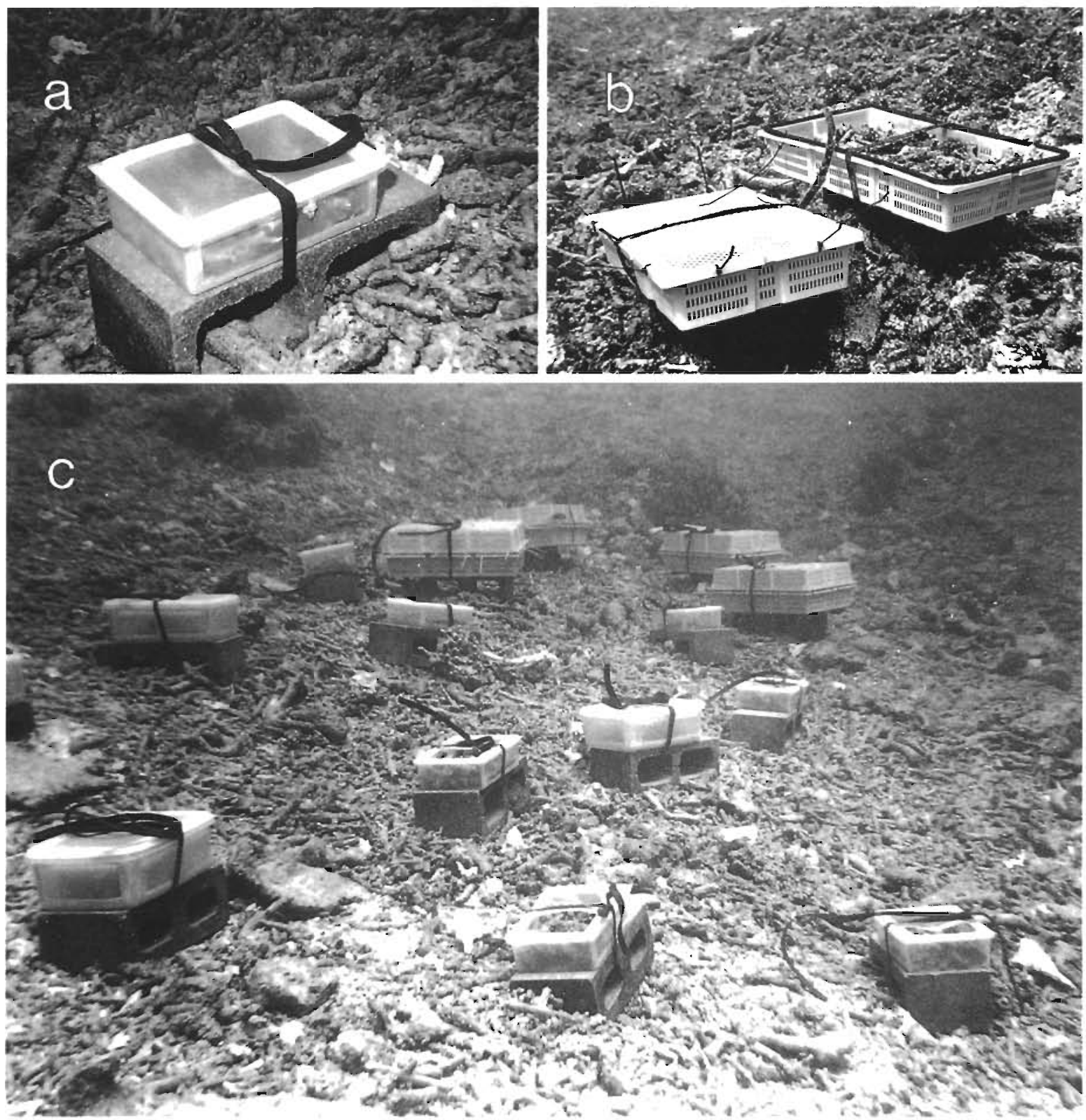

Fig. 1 (a) Small mesh boxes $(26 \times 18 \times 8 \mathrm{~cm})$ fixed to concrete block. This size box was used to deploy 1 - and 4 -mo-old Acanthaster planci. (b) Large mesh boxes $(57 \times 32 \times 9 \mathrm{~cm})$ used to deploy 7 -mo-old starfish. Lid removed from right box to show rubble inside. (c) Dead coral rubble habitat on Davies Reef where experimental deployments were carried out. Large boxes in background are ESCAPE CONTROLS and the left-most box in the foreground is a DOUBLE MESH type box (see text)

divers and brought back to the research vessel where the contents were carefully washed into bottles and the entire contents fixed in buffered $10 \%$ formalin in seawater. The fixative also contained Rose Bengal stain to make subsequent sorting of animals from rubble and debris easier. Prior to fixing, any starfish which could be recovered alive were removed, counted and measured (greatest diameter)
The fixed contents of the boxes were sorted by washing the rubble over 6,1 and $0.1 \mathrm{~mm}$ mesh screens. In this way all rubble was retained in the $6 \mathrm{~mm}$ mesh and starfish and other epifauna were retained by the smaller meshes. Following this, each piece of rubble was individually washed over the mesh. All starfish were then recovered from the mesh screens and counted and measured. The other epifauna in the 
Table 1. Acanthaster planci. Mean size $\pm 1 \mathrm{SD}$ of juvenile starfish recovered after field experiments. nd: no data

\begin{tabular}{|c|c|c|c|c|c|}
\hline \multicolumn{2}{|c|}{ Deployment } & \multirow{2}{*}{$\begin{array}{l}\text { Age } \\
\text { (mo) }\end{array}$} & \multicolumn{2}{|c|}{ Mean size (mm) } & \multirow{2}{*}{$\begin{array}{c}\text { Size range } \\
\text { (mm) }\end{array}$} \\
\hline Date & Length (d) & & Controls & Treatments & \\
\hline Feb 1991 & 6 & 1 & $1.0 \pm 0.1$ & $1.1 \pm 0.1$ & $0.6-1.7$ \\
\hline May 1991 & 13 & 4 & $2.8 \pm 0.1$ & $2.7 \pm 0.2$ & $0.7-4.7$ \\
\hline Aug 1991 & 16 & 7 & $4.9 \pm 0.4$ & $5.5 \pm 0.4$ & $1.4-6.0$ \\
\hline May 1991 & 13 & 16 & nd & $16.2 \pm 0.3$ & $9-23$ \\
\hline
\end{tabular}

$1 \mathrm{~mm}$ screen were also counted and categorised with the aid of a dissecting microscope.

Controls for handling and sorting efficiency. To measure the efficiency of the recovery (sorting) technique, small starfish ( $\mathrm{N}=50$ for 1 -mo-old and $\mathrm{N}=30$ for 4-mo-old) were seeded into each of 4 TREATMENT boxes and the contents were fixed after a few minutes and sorted as for the experimental samples. To ensure that the degree of starfish handling during the counting and deployment procedure did not contribute to starfish mortality, handling controls were also carried out. Two or 4 replicate batches of starfish, which had been subject to the same amount of handling as those placed in the boxes, were kept in dishes overnight and examined the morning following the deployment of boxes.

Analysis. The proportions of surviving starfish in the CONTROLS and TREATMENTS were compared using a $t$-test. Where required an arcsin transformation was used to correct variance structure. Mortality rate was determined to be the daily rate of loss in the TREATMENT boxes. Predation rate was determined to be the difference between the mortality rates in the TREATMENT and CONTROL boxes where a significant difference in survival was detected between the two.

\section{RESULTS}

\section{Starfish size}

Sizes of the different age classes of starfish recovered after each experiment are indicated in Table 1. Mean starfish size remaining in the TREATMENT and CONTROL boxes following recovery was determined to examine for evidence of size-dependent mortality. Table 1 indicates that for 1 - and 4-mo-old Acanthaster planci, on which significant effects of predation were detected, no differences in starfish size existed at the end of the deployment period ( $t$-test, $p>0.05$ ). This indicates no size-selective predation was occurring over the limited size range of starfish present. Sevenmonth-old $A$. planci recovered from the TREATMENT boxes were significantly larger (on average $0.6 \mathrm{~mm}$ larger) than in the CONTROLS ( $t$-test, $p=0.011$ ). This is most likely the result of faster growth in the boxes containing natural rubble, but may indicate that larger starfish were more likely to escape (see below). Note that the 7 -and 16-mo-old starfish are stunted compared to what could be expected on average for starfish of that age in a natural population [e.g. $21 \mathrm{~mm}$ (range: 12 to $28 \mathrm{~mm}$ ) and $77 \mathrm{~mm}$ (range: 34 to $156 \mathrm{~mm}$ ) respectively; Zann et al. (1990)]. The stunting in our laboratoryreared animals is due to an absence of coral food but does not appear to affect the health of starfish for up to 2 yr of age (Lucas 1984, Keesing \& Halford 1992).

\section{Handling and sorting efficiency controls}

No starfish in the handling controls died. The mean number of 1 -mo-old starfish recovered from the sorting efficiency controls was $45.25 \pm 1.71, \mathrm{n}=4$, indicating a $9.5 \%$ loss. In subsequent analyses, this correction factor was added to the number of starfish recovered from each of the natural rubble TREATMENT boxes. For 4-mo-old starfish, all individuals were recovered from the sorting efficiency controls, so no correction factor was necessary.

\section{Survival rates of starfish}

1-mo-old starfish. After deployment in the field for $6 \mathrm{~d}$ (actual time 5.75 d including 5 full night periods), a mean of $62 \%$ of starfish were recovered from the TREATMENT boxes and $92 \%$ were recovered from the CONTROLS (Table 2). This indicates a significant rate of mortality ( $t$-test on transformed data, $p=0.0005$ ) equivalent to about $6.49 \% \mathrm{~d}^{-1}$ in the TREATMENT boxes compared to 1.44 in the CONTROLS. This constitutes a predation rate of $5.05 \% \mathrm{~d}^{-1}$ in the TREATMENT boxes.

4-mo-old starfish. Starfish of this age were deployed for $13 \mathrm{~d}$ and after that time a mean of $85 \%$ of starfish had survived in the TREATMENT boxes compared with $95 \%$ in the CONTROLS (Table 3 ). This $10 \%$ difference was significant ( $t$-test, $\mathrm{p}=0.002$ ) and amounts to a mortality rate of $1.24 \% \mathrm{~d}^{-1}$ in the TREATMENTS and 0.39 in the CONTROLS (predation rate $=0.85 \% \mathrm{~d}^{-1}$ ). 
Table 2. Contents of CONTROL and TREATMENT boxes $6 \mathrm{~d}$ after deployment at Davies Reef. Each box was deployed with 100 juvenile Acanthāster planci (mean size ca $1 \mathrm{~mm}$ i range 0.7 to $1.6 \mathrm{~mm}$ ) initially. Unequal sample sizes resulted from 3 of the samples being lost when the barge carrying them accidentally submerged. Units are mean no. ind. $\pm 1 \mathrm{SD}$; n: no. of replicates

\begin{tabular}{|c|c|c|}
\hline $\begin{array}{l}\text { Fauna recovered } \\
\text { from rubble }\end{array}$ & $\begin{array}{l}\text { Natural rubble } \\
\text { treatment }(\mathrm{n}=9)\end{array}$ & $\begin{array}{c}\text { Aquarium rubble } \\
\text { control }(\mathrm{n}=8)\end{array}$ \\
\hline Small A planci & $62.0 \pm 16.1$ & $92.0 \pm 7.8$ \\
\hline \multicolumn{3}{|l|}{ Worms } \\
\hline Mostly polychaetes & $70.8 \pm 32.7$ & $18.0 \pm 6.3$ \\
\hline Turbellarians & $0.7 \pm 1.3$ & - \\
\hline \multicolumn{3}{|l|}{ Crustaceans } \\
\hline Crabs & $1.1 \pm 1.0$ & - \\
\hline Shrimps & $3.2 \pm 2.8$ & - \\
\hline Galathiads & $2.2 \pm 1.2$ & - \\
\hline Isopods & $2.7 \pm 1.2$ & $3.0 \pm 2.7$ \\
\hline $\begin{array}{l}\text { Others (mostly } \\
\text { amphipods) }\end{array}$ & $33.0 \pm 12.9$ & $2.2 \pm 1.4$ \\
\hline \multicolumn{3}{|l|}{ Molluscs } \\
\hline Gastropods & $7.5 \pm 7.4$ & - \\
\hline Bivalves & $3.0 \pm 1.4$ & $0.5 \pm 1.4$ \\
\hline Chitons & $1.1 \pm 0.9$ & - \\
\hline Opistobranchs & $0.9 \pm 0.6$ & - \\
\hline \multicolumn{3}{|l|}{ Echinoderms } \\
\hline Echinoids & $1.4 \pm 1.3$ & - \\
\hline Ophiuroids & $0.7 \pm 0.7$ & $0.6 \pm 0.7$ \\
\hline Fish & $0.1 \pm 0.3$ & - \\
\hline
\end{tabular}

7-mo-old starfish. After $16 \mathrm{~d}$ deployment a mean of $94 \%$ of starfish were recovered from the TREATMENT boxes and $88 \%$ from the CONTROLS. This difference was not significant ( $t$-test, $p=0.184$ ). As all starfish recovered from the CONTROLS appeared healthy and no potential predators were encountered when sorting through the contents of the boxes it was feared that the majority of starfish missing from the CONTROLS had either somehow escaped between the box and the lid in response to lack of food or had not been sorted and counted efficiently (rubble from CONTROLS was not fixed in formalin and sieved prior to sorting). A trial was carried out a posterion in large aquaria to examine whether starfish would escape from the boxes in the absence of food and to measure the sorting efficiency. The trial, carried out over $5 \mathrm{~d}$, showed that while sorting efficiency was $100 \%, 30 \%$ of the starfish escaped from the boxes that had no substratum and $5 \%$ escaped from the boxes with CONTROL rubble. Thus we expect that the lower rate of recovery of starfish from the CONTROL boxes in the field experiment was due largely to escape.

The mean percentage of Acanthaster planci recovered from the OPEN boxes was $93 \%$. There was no significant difference between this and the percentage
Table 3. Contents of CONTROL and TREATMENT boxes $13 \mathrm{~d}$ after deployment. Each box was deployed with 35 juvenile Acanthaster planci (mean size ca $3 \mathrm{~mm}$; range: 1.5 to $4.5 \mathrm{~mm}$ ) initially. Units are mean no. ind. $\pm 1 \mathrm{SD} ; \mathrm{n}$ : no of replicates

\begin{tabular}{|lcc|}
\hline $\begin{array}{l}\text { Fauna recovered } \\
\text { from rubble }\end{array}$ & $\begin{array}{c}\text { Natural rubble } \\
\text { treatment }(\mathrm{n}=10)\end{array}$ & $\begin{array}{c}\text { Aquarium rubble } \\
\text { control }(\mathrm{n}=10)\end{array}$ \\
\hline Small $A$. plancl & $30.1 \pm 2.4$ & $33.4 \pm 1.7$ \\
Worms & & \\
$\quad$ Mostly polychaetes & $47.4 \pm 13.1$ & $16.1 \pm 6.9$ \\
Turbellarians & $0.5 \pm 1.1$ & $0.1 \pm 0.3$ \\
Crustaceans & $1.8 \pm 0.9$ & - \\
Crabs & $4.2 \pm 3.0$ & $0.1 \pm 0.3$ \\
Shrimps & $6.9 \pm 6.5$ & $1.4 \pm 1.9$ \\
Isopods & $19.0 \pm 11.6$ & $0.1 \pm 0.3$ \\
Others (mostly & & \\
amphipods) & & - \\
Molluscs & & - \\
Gastropods & $45.5 \pm 13.8$ & - \\
Bivalves & $9.2 \pm 2.3$ & - \\
Chitons & $1.1 \pm 0.9$ & $0.1 \pm 0.3$ \\
Echinoderms & & \\
Echinoids & $1.0 \pm 0.9$ & - \\
Ophiuroids & $0.9 \pm 1.3$ & - \\
Fish & $0.3 \pm 0.5$ & \\
\hline
\end{tabular}

recovered from the TREATMENT boxes ( $t$-test, $\mathrm{p}=$ $0.816)$. These data indicate firstly, that exposing the starfish to mobile predators outside the boxes did not contribute significantly to the mortality rate over the deployment period. Secondly, they indicate that few starfish escaped from the OPEN boxes and that leaving the lids off the boxes did not contribute significantly to the escape rate. So although escape from the TREATMENT boxes cannot be ruled out we suggest the measured mortality rate of $0.45 \% \mathrm{~d}^{-1}$ is reasonable.

16-mo-old starfish. No starfish were lost from the experimental deployment of this age class over $13 \mathrm{~d}$. Longer deployments using larger enclosures will be required to assess whether mortality rates of these larger starfish are high enough in field populations to be detected.

\section{Escape controls}

Results from the recovery of starfish from the ESCAPE controls (Table 4) indicate that starfish move very little initially and become more mobile as they grow. None of the 1-mo-old starfish moved from the inner to the outer section of the boxes. The low rates of movement in the larger starfish suggests that in the future these can be deployed in larger OPEN boxes for longer periods which may provide greater information on predation rates. 
Table 4. Acanthaster planci. Proportion of juvenile starfish recovered from ESCAPE control boxes after field experiments. All starfish were initially placed in the inner boxes; 50 starfish per box at Age 1 mo, 20 at 7 mo and 10 at 16 mo. Calculation of percentage escaped assumes that starfish unaccounted for died in the inner and outer boxes in proportion to the living ones recovered from those boxes. n: no. of replicates

\begin{tabular}{|c|c|c|c|c|c|c|}
\hline \multicolumn{2}{|c|}{ Deployment } & \multirow{2}{*}{$\begin{array}{l}\text { Age } \\
\text { (mo) }\end{array}$} & \multirow{2}{*}{$\begin{array}{l}\text { Inner box } \\
x \pm 1 \text { SD }\end{array}$} & \multirow{2}{*}{$\begin{array}{l}\text { Outer box } \\
x \pm 1 \text { SD }\end{array}$} & \multirow[t]{2}{*}{$\%$ Escaped } & \multirow[t]{2}{*}{$\mathrm{n}$} \\
\hline Date & Length (d) & & & & & \\
\hline Feb 1991 & 6 & 1 & $44.5 \pm 0.7$ & $0.0 \pm 0.0$ & 0 & 2 \\
\hline Aug 1991 & 16 & 7 & $16.6 \pm 1.5$ & $2.0 \pm 1.0$ & 11 & 5 \\
\hline May 1991 & 13 & 16 & $7.8 \pm 2.2$ & $2.2 \pm 2.2$ & 22 & 5 \\
\hline
\end{tabular}

\section{Water exchange in boxes}

Fluctuations in dissolved oxygen content of water in the CLOSED box demonstrate the effects of obstructing water flow to the epibenthic community living on dead coral rubble (Table 5). Deprived of any water exchange, oxygen levels in the CLOSED box rose rapidly to more than double that of normal by the second day and then plummeted to only $20 \%$ of normal after $3 \mathrm{~d}$. Slight elevation followed by depression of oxygen levels in the DOUBLE MESH boxes indicates that some significant reduction in water flow was occurring. Oxygen levels in the TREATMENT boxes were unaffected over the $4 \mathrm{~d}$ examined. All visible flurocene had cleared from the TREATMENT boxes within $10 \mathrm{~min}$. Substantial amounts of the dye remained in the DOUBLE MESH box after $30 \mathrm{~min}$ but had cleared completely after $3 \mathrm{~h}$. These results made us confident that sufficient water exchange was occurring in the TREATMENT boxes and not contributing to survival rates of starfish.

\section{Rubble epifauna}

Assessment of the motile epifauna present among the natural rubble indicated that worms, crustaceans and molluscs were common amongst the rubble (Tables $2 \&$ 3). Polychaetes, amphipods and gastropods made up most of the mobile epifauna, although crustaceans such as crabs and shrimps were also found in the samples. It is likely that some of these animals would be predators of the small starfish. Non-mobile epifauna were not quantified but included corals, bryozoa, zoanthids, sponges and oysters

\section{DISCUSSION}

\section{Mortality rates}

Mortality rates for Acanthaster planci in field populations have been measured at $99.3 \%$ between 8- and 23-mo-old $\left(1.08 \% \mathrm{~d}^{-1}\right)$ (Zann et al. 1987) and $75 \%$ between 22 - and 34 -mo-old $\left(0.39 \% \mathrm{~d}^{-1}\right)$ (Doherty \& Davidson 1988). Mortality rates for younger starfish have not previously been presented and our results confirm an expected age-dependent decrease in mortality, based on the assumption that caging was restricting mortality of the larger starfish in the boxes. The high rates of mortality in 1-mo-old starfish found in this study also indicate that mortality levels following settlement are very high and thus have the potential to influence the population dynamics of $A$. planci.

All measured rates of mortality for Acanthaster planci (i.e. Zann et al. 1987, Doherty \& Davidson 1988, this study) have come from populations with very high (= outbreak) densities. If mortality rates are densitydependent then these rates may be lower than might be expected in low density populations. McCallum et al. (1989) have discussed how predators with a type II functional response (sensu Holling 1959) could greatly affect population dynamics of $A$. planci at low densities. On the other hand if predators exhibit a type III

Table 5. Dissolved oxygen content of water $\left(\mathrm{mg} \mathrm{l}^{-1}\right.$; mean $\pm 1 \mathrm{SD}$ ) sampled from TREATMENT boxes 0 to $4 \mathrm{~d}$ after deployment. n: no. of replicates; nd: no data

\begin{tabular}{|c|c|c|c|c|c|}
\hline Water sampled from & $\mathrm{n}$ & Day 0 & Day 2 & Day 3 & Day 4 \\
\hline Water column & 2 & $6.5 \pm 0.1$ & nd & $6.6 \pm 0.0$ & $6.6 \pm 0.0$ \\
\hline Interstitial water & 2 & $6.4 \pm 0.1$ & nd & nd & $6.7 \pm 0.1$ \\
\hline Mesh box & 2 & $6.4 \pm 0.1$ & nd & $6.6 \pm 0.1$ & $6.6 \pm 0.1$ \\
\hline Double mesh box & 2 & $6.3 \pm 0.2$ & nd & $6.8 \pm 0.5$ & $5.4 \pm 1.1$ \\
\hline Closed box & 2 & $6.5 \pm 0.1$ & $14.3 \pm 0.1$ & $1.4 \pm 0.7$ & nd \\
\hline
\end{tabular}


functional response (Ormond et al. 1990) then predation rates at low density will be disproportionately lower than at high density. Now that the techniques described here have been tested it is planned to repeat the experiments described here, examining the influence of starfish density on mortality rates. Densitydependent mortality in newly settled non-sessile marine invertebrates (abalone) has been demonstrated by McShane (1991). He suggested that intraspecific competition for favourable living sites resulted in higher levels of predation and dislodgment by strong water movement at high densities.

Acanthaster planci have been observed in the laboratory to have strong preferences to settle on particular substrates, perhaps induced by some chemical cue provided by bacteria (Johnson et al. 1991). Just how important these settling preferences are in determining post-settlement survival rates is not known. However juvenile starfish in our experiments moved very little, suggesting that settlement in areas where predators are few would enhance survival rates. This type of behaviour is known to enhance survival in echinoids (Highsmith 1982) and ascidians (Young 1989). However preferential settlement in areas of favourable food supply would also enhance survival as suitable food availability is known to greatly affect growth rates (Lucas 1984, Keesing \& Halford 1992).

The only other published information on mortality rates of newly settled echinoderms in the field is that of Rowley (1990) who recorded change in density of newly settled sea urchins in 2 habitats and found that mortality over the first $40 \mathrm{~d}$ or so was $5.59 \% \mathrm{~d}^{-1}$ in kelp beds and $3.10 \% \mathrm{~d}^{-1}$ outside kelp beds. Such habitat differences may also be important for survival rates of Acanthaster planci. Yokochi et al. (1988) recorded recruitment rates of 0.82 ind $\mathrm{m}^{-2}$ on the slope and 0.06 ind $\mathrm{m}^{-2}$ on the reef flat of the same reef. Zann et al. (1987) also found within-reef differences in recruitment rates. It is not known whether these differences result from differential levels of settlement or postsettlement mortality or a combination of both. Black \& Moran (1991) have demonstrated how small scale hydrodynamics may influence settlement density of A. planci within reefs. To determine whether the most significant influences on $A$. planci population dynamics take place pre- or post-settlement, studies which seek to isolate settlement rates from recruitment rates will be vital.

\section{Techniques}

Whilst other studies have monitored the survival rates of newly settled marine invertebrates (e.g. Luckenbach 1984, Rowley 1990) and carried out laboratory experiments on survival rates of reared juveniles (e.g. Highsmith 1982), ours is the first study to our knowledge undertaking field deployment of large numbers of juveniles reared in the laboratory. This approach has been necessary because, despite large numbers of outbreaks of adults, juveniles are rarely encountered in the field (Johnson 1992) and certainly not in numbers required for manipulative ecological experimentation.

This study has demonstrated that the techniques outlined allow measurement of mortality rates of small non-sessile benthic animals in the field allowing for partitioning the effects of predator-and non-predatorinduced mortality. The low rates of movement detected for the starfish suggests that in the future they can be deployed in OPEN boxes for long periods. This will provide greater information on predation rates and overcome the problem of artificially excluding the larger mobile predators such as fish which occurs in the boxes with lids.

Because our experiments excluded these large mobile predators, the extent to which our measured rates of mortality are typical of nature is not known. With both predator and prey caged, interactions between the starfish and larger more mobile prey are not adequately measured. This means that at present our measured rates of mortality are likely to be underestimates, particularly at ages greater than 1 mo.

Schiel \& Welden (1987) found that laboratoryreared abalone had less well-developed predator avoidance behaviour than wild-caught abalone and were thus significantly more vulnerable to predation. It is not known how our laboratory reared Acanthaster planci compare with wild starfish although they exhibit the same diel pattern of remaining cryptic during the day and emerging at night to feed as has been recorded for large juvenile starfish in the field (Keesing 1990).

Acknowledgements. We are very grateful to the many people who assisted us with this work. In particular we thank Claudia Chiappetti, Karina Hall and Debbie Wheeler who helped rear larvae and spent many hours sorting samples in the laboratory. Debbie Bass, Caroline Christie, Hugh Griffith, Mark Hall, Ken Okaji, Regula Meierhofer, Ian Miller, Sue Mitchell, Nigel Snell, Angus Thompson, Emre Turak and the masters and crews of the RV 'Lady Basten' and RV 'Sirius' helped out in the field. Many people were involved in discussions on the formulation of the techniques described in this paper, in particular Masashi Yamaguchi, John Lucas, Craig Johnson, Peter Moran and Russ Babcock, and the manuscript was greatly improved with comments from Tony Fowler and 3 anonymous reviewers. The study was supported by funds from the Great Barrier Reef Marine Park Authority's Crown of Thorns Starfish Research Committee (COTSREC). 


\section{LITERATURE CITED}

Birkeland, C., Lucas, J. S. (1990). Acanthaster planci: major management problem of coral reefs. CRC Press, Boca Raton

Black, K. P, Moran, P. J. (1991). Influence of hydrodynamics on the passive dispersal and initial recruitment of larvae of Acanthaster planci (Echinodermata: Asteroidea) on the Great Barrier Reef. Mar. Ecol. Prog. Ser. 69: 55-65

Cameron, R. A., Schroeter, S. C. (1980). Sea urchin recruitment: effect of substrate selection on juvenile distribution. Mar. Ecol. Prog. Ser. 3: 243-247

Doherty, P. J., Davidson, J. (1988). Monitoring the distribution and abundance of juvenile Acanthaster planci in the central Great Barrier Reef. Proc. 6th Int. Coral Reef Symp. 2: $131-136$

Highsmith, R. C. (1982). Induced settlement and metamorphosis of sand dollar (Dendraster exentricus) larvae in predator free sites: adult sand dollar beds. Ecology 63(2): $329-337$

Holling, C. S. (1959). The components of predation as revealed by a study of small mammal predation of the European pine sawfly. Can. Entomol. 91: 293-320

Johnson, C. R. (1992). Settlement and recruitment of Acanthaster planci on the Great Barrier Reef: questions of process and scale. Aust. J. mar. Freshwat. Res, 43: 611-627

Johnson, C. R., Sutton, D. C., Olson, R. R., Giddins, R. (1991). Settlement of crown-of-thorns starfish: role of bacteria on surfaces of coralline algae and a hypothesis for deepwater recruitment. Mar. Ecol. Prog. Ser. 71: 143-162

Keesing, J. K. (1990). Feeding biology of the crown-of-thorns starfish. Acanthaster planci (Linnaeus). Ph.D. thesis, James Cook University of North Queensland

Keesing, J. K., Halford, A. R. (1992). The importance of postsettlement processes to the population dynamics of Acanthaster planci (L.). Aust. J. mar. Freshwat. Res. 43 $635-651$

Keough, M. J. (1986). The distribution of a bryozoan on seagrass blades: settlement, growth and mortality. Ecology 67: 846-857

Keough, M. J., Downes, B. J. (1982). Recruitment of marine invertebrates: the role of active larval choices and early mortality. Oecologia 54: 348-352

Lucas, J. S. (1973). Reproductive and larval biology of Acanthaster planci (L.) in Great Barrier Reef waters. Micronesica 9: 197-203

Lucas, J. S. (1984). Growth and maturation of Acanthaster planci (L.) (Asteroidea) and hybrids in the laboratory including observations on the effects of diet. J. exp. mar. Biol. Ecol. 79: 129-147

Luckenbach, M. W. (1984). Settlement and early postsettlement survival in the recruitment of Mulinia lateralis

This article was submitted to the editor
(Bivalvia). Mar. Ecol. Prog. Ser. 17: 245-250

McCallum, H. I., Endean, R., Cameron, A. M. (1989) Sublethal damage to Acanthaster planci as an index of predation pressure. Mar. Ecol. Prog. Ser. 56: 29-36

McShane, P. E. (1991). Density-dependent mortality of recruits of the abalone Haliotis rubra (Mollusca: Gastropoda). Mar. Biol. 110: 385-389

Ormond, R. F. G., Bradbury, R. H., Bainbridge, S., Fabricius, K., Keesing, J., DeVantier, L. M., Medlay, P., Steven, A (1990). Test of a model of regulation of crown-of-thorns starfish by fish predators. In: Bradbury, R. H. (ed.) Acanthaster and the coral reef: a theoretical perspective. Lecture notes in biomathematics, No. 88. Springer Verlag, Berlin, p. 189-207

Rowley, R. J. (1989). Settlement and recruitment of sea urchins (Strongylocentrotus spp.) in a sea urchin barren ground and a kelp bed: are populations regulated by settlement or post-settlement processes? Mar. Biol. 100 $485-494$

Rowley, R. J. (1990). Newly settled sea urchins in a kelp bed and sea urchin barrens: a comparison of growth and mortality. Mar. Ecol. Prog. Ser. 62: 229-240

Schiel, D. R., Welden, B. C. (1987). Responses of predators of cultured and wild red abalone, Haliotis rufescens, in laboratory experiments. Aquaculture 60: 173-188

Yamaguchi, M. (1974). Growth of juvenile Acanthaster planci (L.) in the laboratory. Pacif. Sci. 28: 123-138

Yokochi, H., Ogura, M. (1987). Spawning period and discovery of juvenile Acanthaster planci (L.) (Echinodermata: Asteroidea) at Northwestern Iriomote-Jima, Ryukyu Islands. Bull. mar. Sci. 41(2): 611-616

Yokochi, H., Ueno, S., Ogura, M., Nagai, A., Habe, T. (1988). Recruitment, diet and growth of juvenile Acanthaster planci on reefs in a recovery phase. Proc. 6th Int. Coral Reef Symp. 2: 110

Young, C. M. (1989). Selection of predator free settlement sites by larval ascidians. Ophelia 30(2): 131-140

Young, C. M., Chia, F.-S. (1982). Factors controlling spatial distribution of the sea cucumber Psolus chitonoides: settling and post-settling behaviour. Mar. Biol. 69: 195-205

Young, C. M., Chia, F.-S. (1984). Microhabitat-associated variability in survival and growth of subtidal solitary ascidians during the first 21 days after settlement. Mar. Biol. 81. 61-68

Zann, L., Brodie, J., Berryman, C., Nakasima, M. (1987). Recruitment, ecology, growth and behaviour of juvenile Acanthaster planci (L.) (Echinodermata: Asteroidea). Bull. mar. Sci. 41(2): 561-575

Zann, L., Brodie, J., Vuki, V. (1990). History and dynamics of the crown-of-thorns starfish Acanthaster planci (L.) in the Suva area, Fiji. Coral Reefs 9: 135-144

Manuscript first received: November 29, 1991

Revised version accepted: June 23, 1992 